\title{
Influence of Cognitive Factors on Self-Employment Intention Among Students in Technical, Vocational Education and Training in Kenya
}

\author{
David Maina Kahando ${ }^{1} \&$ Esther Nyambura Mungai ${ }^{1}$ \\ ${ }^{1}$ School of Business and Management Studies, The Technical University of Kenya, Kenya \\ Correspondence: Esther Nyambura Mungai, School of Business and Management Studies, The Technical University \\ of Kenya, Kenya.
}

Received: July 3, 2018

doi: 10.5430/ijba.v9n5p21
Accepted: August 1, 2018

Online Published: August 7, 2018

URL: https://doi.org/10.5430/ijba.v9n5p21

\begin{abstract}
Entrepreneurship has been identified as a crucial activity for economic growth and employment generation worldwide. However, this has not been effective in most developing countries, Kenya as an example, has a high rate of unemployment among the young graduates emerging from universities and tertiary institutions. One of the government challenges is transforming the mindset of students to venture into business rather than seeking employments. This study thus examined the relationship between cognitive factors, entrepreneurship education and how these variables influence self-employment intentions among Technical and Vocational Education and Training in Kenya. The study objectives were to determine the influence of cognitive factors and the moderating effect of entrepreneurship education on students' self-employment intentions. The study adopted a survey research design. Self-administered questionnaire was developed and administered to 400 diploma engineering finalist sampled from 41 public Institutions spread in five geographical regions in the country using multistage and simple random sampling approach. The data were analyzed using descriptive statistics and inferential statistics with the help of the Statistical Package for Social Sciences version 20. Pearson's Coefficient Correlation was used to examine reliability of data. Factor analysis was conducted to investigate the internal structure among the set of variables. Multiple linear regressions analysis was used to examine the effect of independent variables on the dependent variable. The results of findings showed that there was a positive and significant relationship between cognitive factors and self-employment intention. The results also showed that entrepreneurship education enhances cognitive factors and thus strongly influence self-employment intentions.
\end{abstract}

Keywords: cognitive factors, self-employment intentions, entrepreneurship education

\section{Introduction}

Entrepreneurship is increasingly being acknowledged as a key driver of economic growth across National economies. The emergence of new and innovative business start- ups has positively impacted economic growth of nations globally. A recent report by the Global Entrepreneurship Monitor (Global Entrepreneurship Monitor, 2010) indicate that Entrepreneurship activities account for one-third of economic growth in over forty member countries. Given the contributions of entrepreneurship in steering economic development, it is the desire of every nation to increase entrepreneurial activities. One way to achieve this is inculcation of entrepreneurial culture through entrepreneurship education (Bwisa, 2004).

Entrepreneurship education (EE) was dated back to 1876 with the economic and agricultural literature and included the start of Harvard courses in 1947 (Katz, 2003 \& Global Entrepreneurship Monitor, 2010) describes entrepreneurship education the building of knowledge and skills either "about" or "for the purpose of" entrepreneurship generally, as part of recognized education programs at primary, secondary, tertiary or university -level educational institutions. Entrepreneurship Education is seen as a means of producing manpower for economic growth and development. In Kenya, the growth of entrepreneurship education is mainly triggered by current government policies and programmes geared towards the promotion of entrepreneurship (Souitaris et al., 2007). Such programs are designed to promote preference for self-employment as a viable career option. Higher education institutions such as universities and TVET Institutions in Kenya have developed and included entrepreneurship subjects and courses to be consistent with the Government's mandate that just about all programmes should enable students to gain skills not only for successful corporate work but also for self-employment. Technical and vocational education and training (TVET) remains a key development strategy for international development agencies and governments (King, 2010 \& McGrath, 2002). TVET 
institutions in Kenya are governed by the respective government departments which set policy, accredit and fund them under their purview. The Kenya Institute of Curriculum Development (KICD) continue to oversee development of curricular for TVET while Kenya National Examinations Council (KNEC) administers examination.

Entrepreneurship education is instrumental in increasing positive attitude towards entrepreneurship among the youth (Potter, 2008). Given the persistent unemployment problem among the Kenyan youth, most recently, the government through sessional paper No 1 of 2015 reemphasized the need for TVET Institutions to incorporate entrepreneurship education as a core unit in TVET education curricular. However, despite the aforementioned government efforts, the anticipated impact of entrepreneurship education on employment creation, high unemployment levels among the youth especially TVET graduates remain a major concern, since only a small percentage actually become entrepreneurs after graduation (Brijlal, 2011). The problem is further heightened by the sustained preference by a larger number of graduates from both universities and TVET institutions for paid employment as opposed to venturing into selfemployment (Kilemi, 2002 \& Kinyanjui, 2007). Thus, a substantial gap continues to exist and substantively increase between the expected and the actual level of graduate involvement in entrepreneurship activities (Kiiru et al., 2015). Although a number of these investigations have been conducted in universities and institutions of higher learning on students' entrepreneurial intentions, very few have conducted research on students' entrepreneurial intentions in vocational institutions who have unique programmes.

Most of these studies did not consider, first, the effect of students' level of education and entrepreneurial orientation (TVET versus University) when choosing between self-employment and formal employment career options (Mungai, 2012). Secondly, the effect of EE as a compulsory unit in TVET institutions as compared to University who offer it as a voluntary course. Thirdly, TVET curriculum uniquely offers hands-on technical skills which are competency based compared to universities who offer professional courses. As a result, the TVET graduates are expected to display better inclination towards self- employment compared to graduates from universities due to the nature of training. According to (Douglas, 2013), Entrepreneurial intention has been empirically proved to be the best and unbiased predictor of entrepreneurial behavior. There are many cognitive factors that are believed to influence self-employment intention. The cognitive factors are personal attraction, perceived social valuation and perceived self-effectiveness. These factors form the basis of the current study.

\section{Statement of the Problem}

The youth unemployment rate worldwide stands at 71.5 million which represents 13.1 percent of the global population and is expected to rise in the year 2017 (ILO, 2016). In Kenya, over 3 million youth are among the unemployed (Kenya National Bureau of Statistics, 2015). Further (Kenya National Bureau of Statistics, 2015), observes that in that year, only 28 percent of 30,000 youth who graduated from both universities and TVET institutions were absorbed into formal employment. The rest are left out to look for opportunities in the informal sector or simply waste away in idleness. Such reality paints a gleam picture for the Kenyan youth.

This study is a response towards seeking impactful and lasting solution towards resolving unemployment problem among the youth through self-employment. However, despite the government's effort to address the youth unemployment problems through job creation and initiatives to encourage the youth to venture into entrepreneurship activities, more of those who graduate continue to prefer formal career options as instead of self-employment (Mungai, 2014). The effect of such initiatives on unemployment is thus hardly felt. The apparent impasse on unemployment is therefore a big challenge that requires urgent attention (Otuya, 2013). Hence necessity for this research.

Past studies indicate that there are positive effects of entrepreneurship education on curbing unemployment (Peterman, $2003 \&$ Souitaris, 2007). Although most of these findings provide evidence that entrepreneurship education has a positive impact on university graduates' entrepreneurial intention there is however, none which has focused on the effect of entrepreneurship education on entrepreneurial intentions among tertiary institutions' graduates and more specifically TVET institutions in Kenya.

The focus on students within TVET institutions is important given the tailored nature of the curriculum to produce graduates who are more likely to prefer self-employment career options. While there has been significant previous research on the causes and effects of entrepreneurship, there is a lack of thoroughness in past research studies and hence unclear results regarding the effect of entrepreneurship education. In cognizance of these knowledge gaps, it is of theoretical and practical relevance to investigate the moderating effect of entrepreneurship education on cognitive factors on self-employment intentions among TVET students in Kenya. This is forms the major focus of the study.

The specific objectives of the study

The specific objectives of the study were to: 
a) Determine the effect of cognitive factors (personal attraction, perceived social valuation and perceived self-effectiveness) and students' self-employment intentions.

b) Determine the moderating effect of entrepreneurship education on the relationship between cognitive factors and students' self-employment intentions.

Research hypotheses

The research tested the following hypotheses:

$\mathbf{H}_{\mathbf{0}}$ 1. There was no significant relationship between cognitive factors [a) personal attraction, b) social valuation, c) self-effectiveness] and self-employment intentions.

$\mathbf{H}_{\mathbf{0}}$ 2. Entrepreneurship education has no significant moderating effect on the relationship between personality factors and students' self-employment intentions.

Independent Variable

Moderating Variable

Dependent Variable

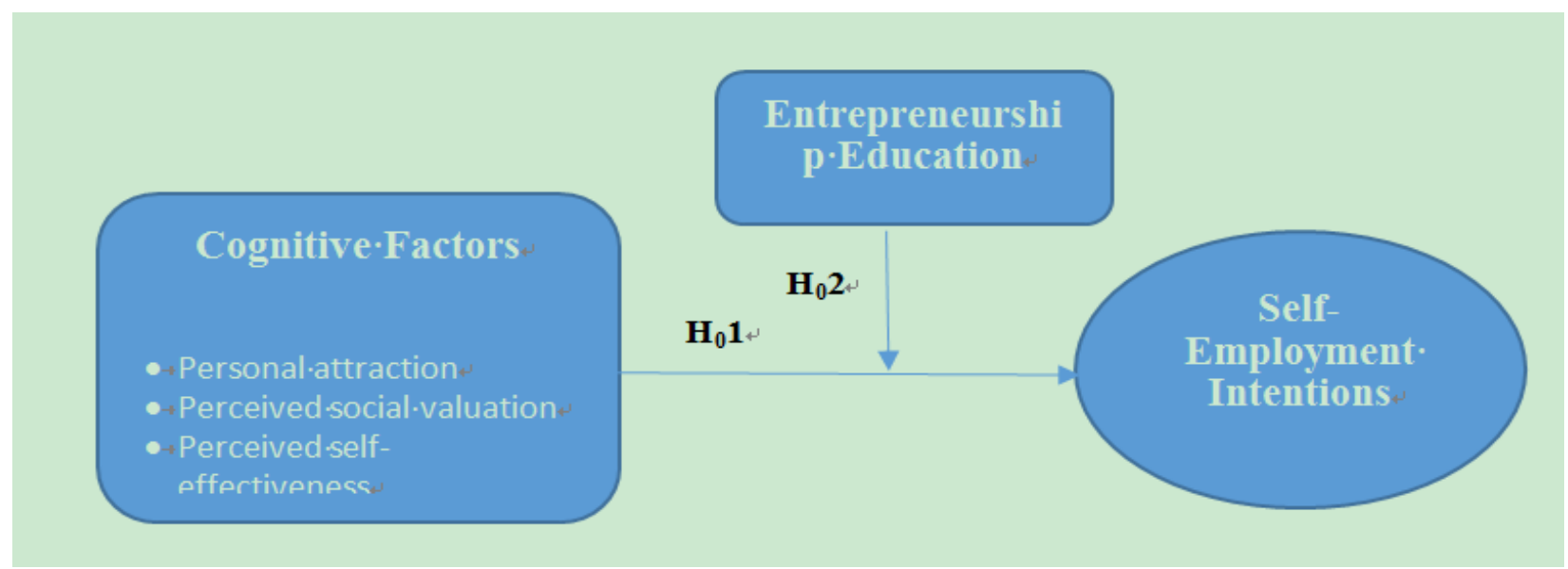

Figure 1. Conceptual framework

\section{Methodology}

\subsection{Research Philosophy}

The positivist paradigm is preferred for the current study since it assumes that a useful research is based on theory, hypotheses and quantitative data (Ridenour, 2008 \& Veal, 2005). Considering that this research is based on theory, hypotheses and quantitative data, the study adopts a positivism paradigm or quantitative approach which involved data collection and the analysis of numerical data (Veal, 2005).

\subsection{Research Design}

The current study used survey design to investigate the underlying relationships between variables. The purpose of using survey design is to provide a quantitative or numeric description of trends, attitudes, or opinion of a population by studying the sample of the population (Babbie, 1990 \& Fowler, 2014). Specifically, this study adopts cross-sectional survey design. In order to achieve the objectives of this study, students from public TVET institutions were sampled to participate in the survey. A questionnaire was developed to measure the response of the students regarding the constructs of the study with reference to conceptual model (figure1). Descriptive statistics and inferential statistical test was used to verify the hypotheses in order to find out the specific effect and relationship between independent variable (cognitive factors and entrepreneurship education) and the dependent variable (self-employment intentions) among TVET students in Kenya. 


\subsection{Study Area}

The study was carried out in 41 public TVET institutions distributed in all regions in Kenya. The institutions are geographically, distributed over five regions in Kenya, namely; Coast Region, Mt Kenya Region, North Rift Region, Nairobi Region, and Western Region.

\subsection{Population of the Study}

The study population consisted of 50,864 students' diploma students registered during the academic year 2014-2016, according to (Kenya National Bureau of Statistics, 2015). This population formed the basis from which the sample for the study was drawn. Due to the large spectrum of courses offered in TVET institutions, the study focused on diploma finalist students in the field of engineering in their final term. For the purpose of this study, engineering courses comprise building construction, civil, electrical and electronic, mechanical and automobile. The finalist engineers' students were thus considered as the population rich with the relevant information for the study.

\subsection{Sampling Technique and Sample Size}

The probability sampling which is commonly associated with survey-based research was used to identify a suitable sampling frame, sample size, and select the most appropriate sampling technique (Kombo, 2006). The sampling unit for the study was finalist engineering students. The study adopted multi-stage sampling as a sampling design. The first stage selected the representative institutions from 41 institutions. Using random sampling, a sample size of 10 Institutions was selected. The second stage was used to select the proportionate sampled units of institutions from each region. In order to avoid bias, the institutions were grouped into that represented the entire country.

The third stage was used to select specific sampled units and the name of institution/s. After proportionately establishing the number of institutions in each region, simple random sampling technique was used. The Final stage was to select the sample of the respondents from each institution. The researcher applied the Slovin's formula in determining the proportionate sample size of students in the 10 institutions. Thus; 400 respondents were selected.

\subsection{Data Collection Procedures}

The study employed designed survey instruments for the research to collect primary data from the respondents. The main data collection instrument used was a self-administered questionnaire to the respondents. The data was collected from diploma finalist students in the field of engineering between October and November 2016 from public TVET institutions. A total of 400 Self-administered questionnaires were distributed to 10 sampled institutions in the five regions. The questionnaire was distributed to all sampled institutions and served to the respondents during class sessions. With the assistance of class teacher, the respondents filled them and returned to the researcher.

\subsection{Test of Reliability and Validity}

The reliability of the instrument was tested using Cronbach's Alpha coefficient which is used to assess the internal consistency or homogeneity among the research instrument items. To ensure the validity of the research questionnaires, the researcher used face validity where a panel of experts and the supervisors gave their input and confirmed that the instrument met the criterion.

\subsection{Pilot Testing}

Before sending out final copy of the instrument to the respondents, pilot survey was conducted in one of TVET Institution. The issues raised by respondents were addressed and the questionnaire refined for the main survey. This institution was not involved in the main survey.

\subsection{Data Analysis and Processing}

The statistical processes which were employed in the analyses of the data comprised the descriptive statistics to more complex procedures like analysis of variance (ANOVA) and inferential statistics. The descriptive statistics comprised frequency distributions, measures of central tendency (means) and measures of dispersion (standard deviation). The descriptive data was analyzed with the help of SPSS 20 software. Inferential statistics which comprised, factor analysis, Pearson correlation analysis, multiple regression analysis involve measurement of relationships among the variables and differences between samples and thus form basis for conclusions. In order to assess the existence of relationship between the dimensions of cognitive factors, entrepreneurship education as a moderating factor and self-employment intention, the Pearson's correlation coefficient ' $r$ ' was computed.

The multiple linear regression models are as follows:

$$
\begin{gathered}
Y=\beta_{0}+\beta_{1} C F+\varepsilon \\
\mathrm{Y} 1=\beta 0+\beta 1 \mathrm{CF}+\beta 2 \mathrm{CFEE}+\varepsilon 0
\end{gathered}
$$


Where: $\mathrm{Y}$ is the self-employment intention (SEI); $\beta_{0}$ is the intercept term; $\beta_{\mathrm{i}}(\mathrm{i}=1,2 \ldots)$ are the regression coefficients; CF is Cognitive Factors; EE is Entrepreneurship Education; and $\varepsilon$ is the random error term. To determine the moderation effect of entrepreneurship education on the relationship between cognitive factors on the one hand and self-employment intention, the products of the moderator and the independent variables were regressed with the dependent variable.

\section{Findings}

\subsection{Sample Characteristics}

Of the targeted 400 respondents, 377 managed to fill the questionnaires, thus yielding to a response rate of $94.3 \%$. The Coast Region had the highest return rate at $100.0 \%$, followed by Rift Valley with a return rate of $98.8 \%$, and Mt Kenya (98. \%), Nairobi (98.7\%) and finally the Western Region which recorded a response rate of $97.2 \%$. Reliability analysis was done using the Cronbach Alpha and the Value obtained for the all the independent variables was 0.966 meaning that they were above the critical value of 0.7 and hence all questions were retained in the study.

\subsection{Descriptive Statistics and Inferential Analysis}

Effect of Cognitive Factors (Personal Attraction, Perceived Social Valuation and Perceived Self-Effectiveness on Students' Self-Employment Intentions and The Moderating Effect of Entrepreneurship Education on the Relationship between Cognitive Factors and Students' Self-employment Intentions were conducted as follow.

3.2.1 Effect of Cognitive Factors (Personal Attraction, Perceived Social Valuation and perceived Self-Effectiveness on Students' Self-Employment Intentions

The first objective was to determine the effect of Cognitive Factors on students' self-employment intentions in TVET institutions in Kenya. The responses were measured through a set of 30 items using five point likert scale with choices ranging from strongly disagree to strongly agree. This objective was studied through three subsections that relate to Personal Attraction, Perceived Social Valuation and Perceived Self-Effectiveness. In addition, the second objective related to the testing of first null hypothesis that stated: There is no significant relationship between cognitive factors $(a)$ personal attraction (b) perceived social valuation and (c) perceived self-effectiveness) and students' self-employment intentions.

In total, ten items in the structured questionnaire were used to measure Personal Attraction variables. Using exploratory factor analysis with principal component varimax rotation method three components with Eigenvalues greater than unity extracted accounting for $82.273 \%$ of the total variance of the 10 items of personal. The three components are 'Satisfaction component', 'Success component' and 'Evaluation component'. This information is presented in Table 2 (Appendix 1).

The multiple regression models of the three components assumed the form:

$$
\mathrm{Y}=\beta \mathrm{o}+\beta 1 \mathrm{XS}+\beta 2 \mathrm{XSS}+\mathrm{XE}+\varepsilon 0
$$

$\mathrm{Y}=$ Self-Employment Intention

$\mathrm{X}_{\mathrm{S}}=$ Satisfaction component

$\mathrm{X}_{\mathrm{SS}}=$ Success component, $\mathrm{X}_{\mathrm{E}}=$ Evaluation component

The null hypothesis $\mathrm{H}_{\mathrm{O}} \mathbf{1}(\mathbf{a})$ that was tested stated that: There is no significant relationship between personal attraction and students' self-employment intentions

The multiple regression models were summarized as:

Self-Employment Intention $=12.34+.652$ Satisfaction Component +.586 Success Component +.433 Evaluation Component. These results are summarized in Table 3. 
Table 3. Regression analysis of the effect of personal attraction on self-employment intention

\begin{tabular}{llllll}
\hline & \multicolumn{2}{c}{ Un standardized Coefficients } & Standardized Coefficients & T & \multirow{2}{*}{ Sig. } \\
\cline { 2 - 4 } & B & Std. Error & Beta & & \\
\hline (Constant) & 12.34 & .560 & & 22.0 & .000 \\
Satisfaction Component & .652 & .416 & .685 & 41.2 & .000 \\
Success Component & .586 & .450 & .579 & 34.8 & .000 \\
Evaluation Component & .433 & .580 & .329 & .557 & .000 \\
\hline
\end{tabular}

Significant at $\mathrm{P}=0.05$ levels; $\mathrm{R}^{2}=54.8 \% ; \mathrm{F}=1100.599, \mathrm{p}=0.000$

From the analysis of variance, the results are significant at .05 levels $(\mathrm{F}=1100.599, \mathrm{p}=0.000)$. This implies that there is a significant relationship between personal attraction and self-employment intention. The results show that there is significant relationship between personal attraction variables and self-employment intention among students in TVET institutions in Kenya. The null hypothesis that there is no significant relationship between personal attraction variables and students' self-employment intentions among students in TVET institutions in Kenya was rejected.

Nine items were used to measure Perceived Social Valuation as cognitive factor. Using factor analysis with principal component varimax rotation method, the rotation converged in three iterations. Factor analysis produced three components with Eigenvalues greater than unity extracted accounting for $65.55 \%$ of the total variance of the nine items of perceived social valuation. The three components are 'Mentor component', 'Value Component' and Significant Other Component'. This information is presented in Table 4 (Appendix 2).

The multiple regression models assumed the form:

$$
\mathrm{Y}=\beta \mathrm{o}+\beta 1 \mathrm{XM}+\beta 2 \mathrm{XV}+\beta 2 \mathrm{XS}+\varepsilon \mathrm{o}
$$

$\begin{array}{lll}\mathrm{Y} & = & \text { Self-Employment Intention } \\ \mathrm{XM} & = & \text { Mentor component } \\ \mathrm{XV} & = & \text { Value Component } \\ \mathrm{XS} & = & \text { Significant other Component }\end{array}$

The null hypothesis $\mathbf{H}_{\mathbf{0}} \mathbf{1}(\mathbf{b})$ that was tested stated that: There is no significant relationship between perceived social valuation and students' self-employment intention

The multiple regression models were summarized as:

Self-Employment Intention $=31.504+.350$ Mentor Component +.264 Value Component +.579 Significant other components. These results are summarized in Table 5.

Table 5. Regression analysis of the effect of perceived social valuation on self-employment intention

\begin{tabular}{llllll}
\hline & \multicolumn{2}{c}{ Un standardized Coefficients } & Standardized Coefficients & \multirow{2}{*}{ T } & \multirow{2}{*}{ Sig. } \\
\cline { 2 - 4 } & $\mathbf{B}$ & Std. Error & Beta & 9.86 & .000 \\
\hline (Constant) & 31.504 & 3.193 & & 4.14 & .000 \\
Mentor Component & .350 & .084 & .240 & 1.60 & .110 \\
Value Component & .264 & .165 & .092 & 13.2 & .000 \\
Significant other component & .579 & .119 & .575 & & \\
\hline
\end{tabular}

Significant at $P=0.05$ levels; $R^{2}=58.3 \% ; F=63.919, p=0.000$

From the analysis of variance, the results are significant at .05 levels $(\mathrm{F}=63.919, \mathrm{p}=0.000)$. This implies that there is a significant relationship between perceived social valuation and self-employment intention. Its evidence from the results of study that the three components namely; Mentor, Value and Significant Other Component showed a positive effect on self-employment intention. The results show that there is significant relationship between perceived social valuation variables and self-employment intention among students in TVET institutions in Kenya. The null hypothesis that there is no significant relationship between perceived social valuation variables and students' self-employment intentions among students in TVET institutions in Kenya was rejected.

In total, nine items in the structured questionnaire were used to measure perceived self-effectiveness. Using factor analysis with principal component varimax rotation method, factor analysis produced two components with 
Eigenvalues greater than unity extracted accounting for $90.16 \%$ of the total variance of the nine items of perceived self-efficacy. The two components are 'Confidence Component' and 'Capacity Component'. Constructs within the nine items guided naming of the two components. This information is presented in Table 6 (Appendix 3).

To tests hypothesis in this section, multiple regression model was conducted.

The multiple regression models assumed the form:

$$
\mathrm{Y}=\beta \mathrm{o}+\beta 1 \mathrm{XCC} 1+\beta 2 \mathrm{XCC} 2+\varepsilon \mathrm{o}
$$

$\mathrm{Y}=$ Self-Employment Intention

$\mathrm{X}_{\mathrm{CC} 1}=$ Confidence Component

$\mathrm{X}_{\mathrm{CC} 2}=$ Capacity Component

The null hypothesis $\mathbf{H}_{\mathrm{O}} \mathbf{1}(\mathbf{c})$ that was tested was stated that: There is no significant relationship between perceived self-efficacy and students' self-employment intentions. The multiple regression models were summarized as:

Self-Employment Intention $=12.240+.483$ (Confidence Component) +.593 (Capacity Component). These results are summarized in Table 7.

Table 7. Regression analysis of the effect of perceived self-efficacy on self-employment intention

\begin{tabular}{|c|c|c|c|c|c|}
\hline & \multicolumn{2}{|c|}{ Un standardized Coefficients } & \multirow{2}{*}{$\begin{array}{l}\text { Standardized Coefficients } \\
\text { Beta }\end{array}$} & \multirow{2}{*}{$\mathbf{T}$} & \multirow{2}{*}{ Sig. } \\
\hline & B & Std. Error & & & \\
\hline (Constant) & 12.24 & .528 & & 23.2 & .000 \\
\hline Confidence Component & .483 & .019 & 685 & 41.2 & .000 \\
\hline Capacity Component & .593 & .023 & .579 & 34.9 & .000 \\
\hline
\end{tabular}

Significant at $P=0.05$ levels; $R^{2}=59.8 \% ; F=43.234, p=0.000$

From the analysis of variance, the results are significant at .05 levels $(\mathrm{F}=43.234, \mathrm{p}=0.000)$. This implies that there is a significant relationship between perceived self-efficacy and self-employment intention. The study thus concluded that the two components namely; Confidence Component and Capacity Component have a positive effect on self-employment intention. The null hypothesis that there is no significant relationship between perceived self-efficacy and students' self-employment intentions among students in TVET institutions in Kenya was rejected.

3.2.2 The Moderating Effect of Entrepreneurship Education on the Relationship Between Cognitive Factors and Students' Self-Employment Intentions

One objective was used to determine the moderating effect of entrepreneurship education on the relationship between cognitive factors and self-employment intention. The data collected was used to test the corresponding hypotheses. The second hypothesis $\mathbf{H}_{\mathbf{0}} \mathbf{2}$ testing the influence of entrepreneurship education on the relationship between cognitive factors and self-employment intention was stated as: Entrepreneurship education has no significant moderating effect on the relationship between cognitive factors and students' self- employment intention.

The results of the multiple regression analysis undertaken are presented in Table 8.

Table 8. Results for the moderating effect of entrepreneurship education on the relationship between cognitive factors and self-employment intentions

\begin{tabular}{|c|c|c|c|c|c|c|c|c|c|}
\hline \multirow[b]{2}{*}{ Model } & \multirow[b]{2}{*}{$\mathrm{R}$} & \multirow[b]{2}{*}{ R Square } & \multicolumn{6}{|c|}{ Change Statistics } & \multirow[b]{2}{*}{$\begin{array}{l}\text { Sig. } F \\
\text { Change }\end{array}$} \\
\hline & & & $\begin{array}{l}\text { Adjusted } \\
\text { R Square }\end{array}$ & $\begin{array}{l}\text { Std. Error of } \\
\text { the Estimate }\end{array}$ & $\begin{array}{l}\text { R Square } \\
\text { Change }\end{array}$ & $\begin{array}{c}\mathrm{F} \\
\text { Change }\end{array}$ & df1 & df 2 & \\
\hline 1 & .443 & .478 & .521 & 1.8914 & .443 & 1233.841 & 2 & 374 & .000 \\
\hline 2 & .519 & .578 & 692 & 1.8981 & .162 & 1421.342 & 1 & 373 & .001 \\
\hline
\end{tabular}

a. Predictors: (Constant), entrepreneurship Education, Personality traits

b. Predictors: (Constant), Entrepreneurship Education, Cognitive Factors, Entrepreneurship Education * Cognitive Factors

c. Dependent variable: self-employment intention 
The results presented in shows that Model 2 with the interaction between entrepreneurship education and cognitive factors accounted for significantly more variance than just entrepreneurship education and personality traits by themselves, $\mathrm{R}^{2}$ change $=0.162, \mathrm{p}=.001$, indicating that there is potentially significant moderation between entrepreneurship education and cognitive factors on students' self-employment intentions in TVET institutions. Two variables were initially included: cognitive factors and entrepreneurship education. These variables accounted for a significant amount of variance in students' self-employment intentions, $\mathrm{R}^{2}=.443, \mathrm{~F}(2,374)=1233.841, \mathrm{p}<.05$. Next, the interaction term between cognitive factors and entrepreneurship education was added to the regression model, which accounted for a significant proportion of the variance in students' self-employment, $\Delta \mathrm{R}^{2}=.162, \Delta \mathrm{F}(1,373)$ $=1421.342, \mathrm{p}<.05$. Scrutiny of the interaction process showed an enhancing effect that due to entrepreneurship education, majority of students expressed their desire to be entrepreneurs rather than being employed. Based on these findings, the hypothesis that the entrepreneurship education has no significant moderating effect on the relationship between cognitive factors and students' self- employment intention was rejected.

A comprehensive analysis of the contribution of the individual variable to the effect on the dependent variable was undertaken. Additionally, it was considered necessary to develop model of overall influence on the dependent variable based on an aggregation of all the independent variables. This study adopted the following general statistical model for the linear relationship between the independent and dependent variables:

$$
\mathrm{Y} 1=\beta \mathrm{o}+\beta 1 \mathrm{CF}+\beta 2 \mathrm{CF} * \mathrm{EE}+\varepsilon \mathrm{o}
$$

Where: Where $\beta_{\mathrm{o}}$ is the constant coefficient $\beta_{1}$ and $\beta_{2}$ are the model regression coefficients that approximate the change in $\mathrm{Y}$ (Self-Employment Intentions) for a unit change in $\mathrm{X}$ (independent variable).

$\mathrm{CF}=$ Cognitive Factors

$\mathrm{CF}^{*} \mathrm{EE}=\mathrm{A}$ Product of Cognitive Factors and Entrepreneurship Education.

$\varepsilon 0=$ the error term

To find the overall influence of the independent variables on the dependent variable, one general hypothesis was tested and it stated: There was no significant effect on the moderated relationship between cognitive factors and students' self- employment intentions. The multiple regression models were summarized as:

Self-Employment Intentions $=5.311+.333 \mathrm{CF}+612 \mathrm{CF} * \mathrm{EE}$

The $F$-ratio in the ANOVA analysis tests whether the overall regression model is a good fit for the data. The result shows that the independent variables significantly predict the dependent variable, $F(4,373)=871.580, p=0.000$.

Table 9. Summary of regression results showing the joint effect of predictor variables on self-employment intention

\begin{tabular}{|c|c|c|c|c|c|}
\hline & \multicolumn{2}{|c|}{ Un standardized Coefficients } & \multirow{2}{*}{$\begin{array}{l}\text { Standardized Coefficients } \\
\text { Beta }\end{array}$} & \multirow[t]{2}{*}{$\mathbf{T}$} & \multirow[t]{2}{*}{ Sig. } \\
\hline & B & Std. Error & & & \\
\hline (Constant) & 5.311 & 2.145 & & 2.476 & .014 \\
\hline $\mathrm{CF}$ & .333 & .059 & .115 & .561 & .000 \\
\hline $\mathrm{CF}^{*} \mathrm{EE}$ & .612 & .001 & .770 & .877 & .000 \\
\hline
\end{tabular}

Significant at $p=0.05$ levels; $R^{2}=66.43 \% ; 871.580, p=0.000$

The results indicate that the combined effect of cognitive factors and entrepreneurship education, $\mathrm{CF} * \mathrm{EE}(\beta=.612)$; is much greater than the effects of the individual predictors, cognitive factors, $\mathrm{CF}(\beta=.333)$ on self-employment intention respectively. This implies that a unit change in any of the moderated variables will yield a corresponding greater change in self-employment intention compared to any of the unmoderated variables. Based on the study findings, the hypothesis that there was no significant joint effect on the moderated relationship between and cognitive factors and students' self- employment intentions was rejected.

\section{Discussion}

Pearson correlation coefficient between cognitive factors and self-employment intention variables $(r=.547, p=.000$; $r=.345, p=.000 ; r=.522, p=.000$ ) shows positive and significant results at .05 levels. This shows that self-employment intentions among student is dependent on one's personal attraction, ones perceived social variation and one's perceived self-efficacy. 
The first component of personal attraction was labelled 'Satisfaction component'. The results show that students largely have positive altitude about self-employment after completing their study at TVET institutions. Another new personal attraction dimension variable, 'Success variable' corresponds to the second component factor extracted. The results indicate that one of the drivers of self-intention is one's own success. The third component factor loading corresponds to 'Evaluation Component of personal attraction. The results show that there is significant relationship between personal attraction variables and self-employment intention among students in TVET institutions in Kenya.

The first perceived social variation component factor loadings corresponded to 'Mentor Component' variable. The results indicated that decision by students to become self-employed after graduation entirely depends on mentorship process from parents and other successful entrepreneurs in the community. The second perceived social variation component was renamed 'Value Component'. These results show that students' self-employment intention is cultivated through the value added to them by family members and those close to them. The third perceived social variation component factor loadings corresponded to 'Significant other Component' variable. Two items that loaded to these variable included statements that measured the extent to which TVET institutions regard the construct of self-employment despite the high risk involved and the extent to which significant others encourage students to become entrepreneurs after college life. These results show that students' self-employment intention is enhanced through significant other such as family members and TVET institutions themselves. The results show that there is significant relationship between perceived social valuation variables and self-employment intention among students in TVET institutions in Kenya.

The first perceived self-efficacy component factor loadings corresponded to 'Confidence Component' variable. The results indicated that entrepreneurship education course has enhanced students' confidence in being self-employed after graduation from college.

The second perceived self-efficacy component factor loadings corresponded to 'Capacity Component' variables. These results indicate that student' self-employment intentions largely depend on perceived self-efficacy that includes creativity and innovation, problem solving and leadership skills necessary to run a business. The results show that there is significant relationship between perceived self-efficacy variables and self-employment intention among students in TVET institutions in Kenya.

The hypothesis testing the influence of entrepreneurship education on the relationship between cognitive factors and self-employment intention was stated as: Entrepreneurship education has no significant moderating effect on the relationship between cognitive factors and students' self- employment intention. The results presented in shows that Model 2 with the interaction between entrepreneurship education and cognitive factors accounted for significantly more variance than just entrepreneurship education and personality traits by themselves, $\mathrm{R}^{2}$ change $=0.162, \mathrm{p}=.001$, indicating that there is potentially significant moderation between entrepreneurship education and cognitive factors on students' self-employment intentions in TVET institutions. In line with these findings, cognitive factors are perceived to be characteristics that influence how people think and make decisions (Busenitz, 2000). When students receive entrepreneurship education, cognitive factors tend to change overtime. The cognitive approach tries to develop an understanding of how people acquire and process information and utilize it to understand the world of entrepreneurship better. (Wickham, 2006) They tend to be more heavily influenced by a person's perception of the situation he/she is involved in.

\section{Summary}

Using exploratory factor analysis with principal component varimax rotation method, three components with Eigenvalues greater than unity extracted accounting for $82.273 \%$ of the total variance of the 10 items of personal attraction. The three factors were labelled as 'Satisfaction component', 'Success component' and 'Evaluation component'. These three factors were used in the multiple regression analysis of personal attraction and self-employment intention. From the analysis of variance, the results were significant at .05 levels $(\mathrm{F}=1100.599$, $\mathrm{p}=0.000$ ) implying that there is a significant relationship between personal attraction and self-employment intention. The null hypothesis that there was no significant relationship between personal attraction variables and students' self-employment intentions among students in TVET institutions in Kenya was rejected. Using factor analysis with principal component varimax rotation method, three components with Eigenvalues greater than unity extracted accounting for $65.55 \%$ of the total variance of the nine items of perceived social valuation. The three components are 'Mentor component', 'Value Component' and Significant Other Component'. The study revealed that the results are significant at .05 levels $(\mathrm{F}=63.919, \mathrm{p}=0.000)$ which implied that there was a significant relationship between perceived social valuation and self-employment intention. The null hypothesis that there is no significant relationship between perceived social valuation variables and students' self-employment intentions among students in TVET institutions in 
Kenya was rejected. Factor analysis produced two components with Eigenvalues greater than unity which accounted for $90.16 \%$ of the total variance of the nine items of perceived self-efficacy. The two components are 'Confidence Component' and 'Capacity Component'. These factors were used in the multiple regression modelling. From the analysis of variance, the results were significant at .05 levels $(\mathrm{F}=43.234, \mathrm{p}=0.000)$ indicating that there was a significant relationship between perceived self-efficacy and self-employment intention. The null hypothesis that there is no significant relationship between perceived self-efficacy and students' self-employment intentions among students in TVET institutions in Kenya was rejected. The results presented showed that with the interaction between entrepreneurship education and cognitive factors, the resulting model accounted for significantly more variance than just entrepreneurship education and personality traits by themselves, $R^{2}$ change $=0.162, p=.001$, indicating that there is potentially significant moderation between entrepreneurship education and cognitive factors on students' self-employment intentions in TVET institutions. It is evident that the interaction process showed an enhancing effect; that due to entrepreneurship education, majority of students expressed their desire to be entrepreneurs rather than being employed. Based on these findings, the hypothesis that the entrepreneurship education has no significant moderating effect on the relationship between cognitive factors and students' self- employment intention was also rejected.

\section{Conclusion}

Based on the summary of the findings, the independent variables (cognitive factors) were found to be fairly associated with self-employment intention among engineering students in TVET institutions in Kenya. This study therefore, concludes that cognitive factors positively influenced self-employment intention among engineering students in TVET institutions in Kenya, this association could be termed as weak. However, with the introduction of entrepreneurship education as a compulsory course among engineering students in TVET institutions in Kenya, more students indicated that they would rather be entrepreneurs rather than be employed. This study therefore, concludes that the inclusion of entrepreneurship education as a compulsory course enhanced cognitive factors and these moderated variables strongly influenced self-employment intention among engineering students in TVET institutions in Kenya.

\section{References}

Babbie, E. (1990). Survey Research Methods. Belmont, CA: Wadsworth Publishing.

Brijlal, P., \& Peters, R. (2011). The Relationship between Levels of Education of Entrepreneurs and Their Business Success. A Study of the Province of Kwazulu-Natal, South Africa, 25(4), 265-275.

Busenitz, L., Gomez, C., \& Spencer, J. (2000). Country institutional profiles: Unlocking entrepreneurial phenomena. Academy of Management Journal.

Bwisa, H. (2004). Entrepreneurship education in Kenya: a reality of plodding on 4th International Conference on Entrepreneurship. USIU, Nairobi.

Douglas, E.J., \& Fitzsimmons, J.R. (2013). Intrapreneurial intentions versus entrepreneurial intentions: distinct constructs with different antecedents. Small Business Economics, 115-132. https://doi.org/10.1007/s11187-012-9419-y

Fowler, F.J. (2014). The Problem with Survey Research. Sage, 43(5).

Global Entrepreneurship Monitor (GEM). (2010). Global Entrepreneurship Monitor: 2010 Global report.

International Labour Organization (ILO). (2016). World employment social outlook: Trend for youth 2016. Geneva.

Katz, J.A. (2003). The chronology and intellectual trajectory of American entrepreneurship education: 1876-1999. Journal of business venturing, 18(2), 283-300. https://doi.org/10.1016/S0883-9026(02)00098-8

Kenya National Bureau of Statistics (KNBS). (2015). Economic Survey. Nairobi: Kenya National Bureau of Statistics.

Kiiru, D., Iravo, M., \& Kamau, J. (2015). Determinants of entrepreneurial intention among vocational technical training institute students in Kenya: a survey of cap youth empowerment institute. Strategic Journals of Business \& Change Management, 2(19), 369-375.

Kilemi, M. (2002). Vocationalization of secondary education: Kenya case study. Journal of Spring, 1(1), 227-305.

King, K., \& Palmer, R. (2010). Planning for Technical and Vocational Skills Development. International Institute for Educational Planning. UNESCO.

Kinyanjui, M.N. (2007). After graduation what next? A Tracer and policy study of youth polytechnic graduates from Kwale, Kitui, Makueni and Taita Taveta. Institute for Development Studies, University of Nairobi. 
Kombo, K.D., \& Tromp, L.A. (2006). Proposal and thesis writing: an introduction. Pauline Publications Africa.

McGrath, R. (2002). Entrepreneurship, Small Firms and Wealth Creation: A Framework Using Real Options Reasoning. Handbook of Strategy and Management, 299-325.

Mungai, E., \& Ogot, M. (2012). Gender, Culture and Entrepreneurship. International Business Research, 175-183.

Mungai, E.N., \& K'Obonyo, P.P. (2014). The moderating effect of entrepreneurship education on the relationship between entrepreneurial perceptions and entrepreneurial intentions. Prime Journal.

Otuya, R., Kibas, P., Gichira, R., \& Martin, W. (2013). Entrepreneurship education: Influencing students' entrepreneurial intentions. International Journal of Innovative Research \& Studies, 2(4), 132-148.

Peterman, N., \& Kennedy, J. (2003). Enterprise education: Influencing students' perceptions of entrepreneurship. Entrepreneurship Theory and Practice. https://doi.org/10.1046/j.1540-6520.2003.00035.x

Potter, J. (2008). Entrepreneurship and higher education: future policy directions. Local Economic and Employment Development (LEED), 313-335. https://doi.org/10.1787/9789264044104-16-en

Ridenour, C.S., \& Newman, I. (2008). Mixed methods research: Exploring the interactive continuum. Carbondale: Southern Illinois University Press.

Souitaris, V., Zerbinati, S., \& Al-Laham, A. (2007). Do entrepreneurship programmes raise entrepreneurial intention of science and engineering students? The effect of learning, inspiration and resources. Journal of Business Venturing, 22(4), 566-591. https://doi.org/10.1016/j.jbusvent.2006.05.002

Souitaris, V., Zerbinati, S., \& Al-Laham, A. (2007). Do entrepreneurship programmes raise entrepreneurial intention of science and engineering students? The effect of learning, inspiration and resources. Journal of Business Venturing, 22(4), 566-591. https://doi.org/10.1016/j.jbusvent.2006.05.002

Veal, B. (2005). Using self-clocking for passive estimation of TCP round-trip times. Doctoral dissertation.

Wickham, P.A. (2006). Strategic Entrepreneurship. Financial Times Prentice Hall.

\section{Appendix 1}

Table 2. Personal attraction rotated component matrix

\begin{tabular}{|c|c|c|c|}
\hline \multirow[t]{2}{*}{ Statements } & \multicolumn{3}{|c|}{ Components } \\
\hline & 1 & 2 & 3 \\
\hline $\begin{array}{l}\text { I consider Self-employment to be a highly desirable career alternative for people } \\
\text { with technical education. }\end{array}$ & .999 & & \\
\hline $\begin{array}{l}\text { I have already written a business plan as a step towards starting my own } \\
\text { business. }\end{array}$ & .999 & & \\
\hline $\begin{array}{l}\text { Although, Self-employment would present more up than downsides, among } \\
\text { various options, I would rather be an entrepreneur. }\end{array}$ & .999 & & \\
\hline $\begin{array}{l}\text { I would rather own my own business than earn a higher salary employed by } \\
\text { someone else or any other promising career. }\end{array}$ & .999 & & \\
\hline A career as entrepreneur is very attractive it involves great satisfactions for me. & .999 & & \\
\hline $\begin{array}{l}\text { To start my own business would be the best way for me to take advantage of the } \\
\text { Entrepreneurship Education course. }\end{array}$ & .107 & .982 & \\
\hline I am willing to make significant personal sacrifices in order to stay in business & .107 & .982 & \\
\hline $\begin{array}{l}\text { Entrepreneurship Education course has not contributed positively towards } \\
\text { becoming self-employed. }\end{array}$ & & & -.825 \\
\hline Being self- employed implies more disadvantages than advantages to me. & & & -.815 \\
\hline Reliability coefficient: Cronbach alpha $($ overall $=0.776)$ & & & \\
\hline
\end{tabular}




\section{Appendix 2}

Table 4. Perceived social valuation rotated component matrix

\begin{tabular}{|c|c|c|c|}
\hline \multirow[t]{2}{*}{ Statements } & \multicolumn{3}{|c|}{ Components } \\
\hline & 1 & 2 & 3 \\
\hline $\begin{array}{l}\text { My parents and other successful entrepreneurs are role models for me in } \\
\text { cultivating self-employment intentions. }\end{array}$ & .857 & .155 & \\
\hline My family business has increased my desire to be self-employed. & .754 & .382 & .221 \\
\hline $\begin{array}{l}\text { I personally know successful entrepreneurs in my community who are willing to } \\
\text { mentor me after graduation. }\end{array}$ & .709 & & .436 \\
\hline The opinion of my family becoming an entrepreneur is very important to me. & .651 & & \\
\hline $\begin{array}{l}\text { My immediate family is willing to provide me with financial support in my } \\
\text { intentions to be self-employed. }\end{array}$ & -.191 & .848 & -.151 \\
\hline My culture does not conflict with entrepreneurial activities. & -.416 & .780 & \\
\hline $\begin{array}{l}\text { The opinions of other people who are important to me influence me a lot to be } \\
\text { self-employed. }\end{array}$ & -.435 & .779 & \\
\hline $\begin{array}{l}\text { In my institution, self-employment after graduation is highly considered } \\
\text { worthwhile, despite the risk involved }\end{array}$ & .207 & .290 & .773 \\
\hline People who are important to me think that I should become an entrepreneur. & -.225 & & .765 \\
\hline
\end{tabular}

Reliability coefficient: Cronbach alpha( overall=.776)

Extraction Method: Principal Component Analysis.

Rotation Method: Varimax with Kaiser Normalization.

a. Rotation converged in 3 iterations.

\section{Appendix 3}

Table 6. Perceived self-effectiveness rotated component matrix

\section{Reliability coefficient: Cronbach alpha( overall=)}

\section{Extraction Method: Principal Component Analysis.}

Rotation Method: Varimax with Kaiser Normalization.

a. Rotation converged in 3 iterations. 